penulis masing-masing.

Setakat ini, agaknya tidak terdapat penerbitan bahan akademis tentang seluruh bahasa Austronesia sebesar yang dikumpulkan dalam buku tersebut. Tambahan pula, mungkin penerbitan buku seperti itu terlalu sulit sekarang ini, dan mungkin seterusnya. Oleh karena itu, buku tersebut akan menolong mengurangi upaya yang menjemukan untuk mencari bahan-bahan sebidang dalam jurnal dan buku.

Sedalam-dalam penulis dalam buku ini sudah menerangkan fakta bahasa dalam rumpun bahasa Austronesia dan bahasa-bahasa yang berkembang masing-masing, agaknya muncul deskripsi dan/atau istilah yang tidak cocok bagi aliran atau pengetahuan tiap pembaca. Namun, bagi peminat linguistik deskriptif yang belum memulai penelitian, penjelasan dalam buku ini menjadi bantuan yang gemilang, karena tesis, termasuk acuannya, akan memberi pengetahuan yang meluaskan penelitian.

Buku ini layak dan penting dibaca baik oleh ahli bahasa maupun pemelajar yang ingin mempelajari linguistik bahasa-bahasa Austronesia, selain juga menjadi rujukan yang baik. Barangkali buku ini akan menjadi pilihan pertama yang memandu pembaca untuk melayari kelautan linguistik Austronesia dengan selamat: selagi memegang buku ini, tidak berlebihan, saya yakin pembaca tidak akan tersesat.

Yuko Kitada
Program Studi Linguistik, Tokyo University of Foreign Studies, Tokyo, Jepang

\title{
Membuka Kedok Korupsi dalam Masyarakat
}

Al. Andang L.Binawan (ed). Korupsi Kemanusiaan. Jakarta: Penerbit Buku Kompas, 2006), xx + 234 halaman.

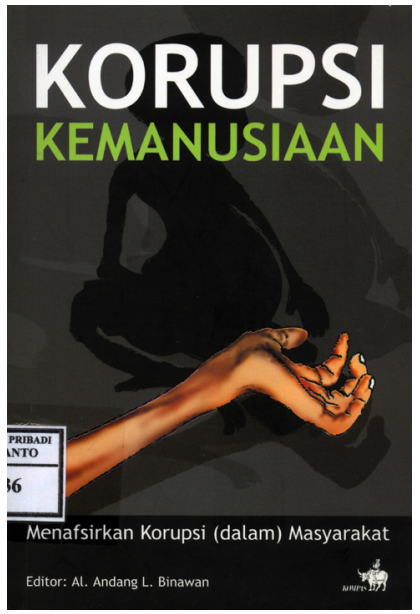

Buku ini merupakan kumpulan karangan festschrift (penghormatan) terhadap Romo Magnis Suseno pada hari ulang tahunnya ke- 70. Kumpulan karangan yang menguraikan tafsir korupsi dari sudut pandang etika, nilai humanistis dan sosial budaya. Berbagai perspektif diuraikan dengan gamblang dan mudah dipahami, seperti: praktik korupsi yang sanggup merusak wacana tentang korupsi, logika koruptif dalam kerja jurnalistik, cengkeraman kapitalisme transnasional, pembusukan pandangan terhadap dunia, kekuasaan voyeuristik dalam masyarakat, hakikat manusia Feuerbachian, eksistensi manusia, penghayatan hidup individu, toleransi moral 
dan budaya permisif, hermenutika di zaman global dan jalan menuju perdamaian.

Pemahaman secara umum mengenai korupsi sering diartikan sebagai penyalahgunaan kekuasaan jabatan atau kekuasaan publik untuk keuntungan pribadi. Apakah memang demikian pemahaman tentang korupsi ataukah ada hal lain yang dapat diungkap mengenai korupsi. Melalui kerangka filsafat komunikasi Habermas, wacana korupsi diteropong oleh Ignas Kleden. Ia ingin membuktikan apakah wacana Habermas dapat diterapkan untuk menganalisis gejala korupsi . Menurut Habermas, teori wacananya lahir karena pergulatannya dengan teori bahasa dan linguistic turn, yaitu semakin dominannya teori bahasa dalam ilmu sosial dan filsafat (hlm.1). Kerangka Habermas bertolak dan merupakan komposisi empat jenis kebenaran yaitu (1) kebenaran linguistik, (2) kebenaran epistemologis, (3) kebenaran psikologis, dan (4) kebenaran moral (hlm.6). Korupsi sebagai wacana dapat diteropong dari empat perspektif kebenaran tersebut. Di sisi lain harus dipahami bahwa kekuatan empat syarat tersebut memiliki perbedaan dan tidak bisa diperlakukan setara, tergantung dari situasi, kondisi masyarakat dan bagaimana korupsi itu muncul. Melalui penerapan wacana Habermas, Ignas berpendapat, setidaknya keempat syarat tersebut dapat menolong untuk melakukan identifikasi pada titik mana penyelewengan atau distorsi itu muncul, apakah pada tingkat epistemologis, linguistik, psikologis ataukah moral (hlm.15)

Tulisan lain yang berjudul 'Menolak logika koruptif dalam kerja jurnalistik' dari Maria Hartiningsih memaparkan bagaimana distorsi komunikasi itu terjadi dalam media massa, terutama pada media cetak. Distorsi komunikasi berada pada peminggiran yang disengaja terhadap kelompok yang terpinggirkan, yang lemah dan miskin. Pengalamannya sebagai jurnalis selama 20 tahun telah membukakan dirinya untuk melihat jurang antara realitas sosial yang riil dalam hidup keseharian warga dengan hal yang ideal yang dibicarakan dalam berbagai konferensi internasional (hlm.18). Selain itu, posisi war journalism dan peace journalism membuat para jurnalis harus memikirkan dan mendengarkan suara hatinya agar apa yang ingin disampaikan atau diinformasikan bernafaskan objektivitas dan tetap dipengaruhi oleh kesadaran kita atau menurut Maria disebut sebagai mindset yang dinamis, disertai pengalaman dan pilihan hidup.

Keprihatinan tertuju pada cara bagaimana negeri ini dikelola dan didominasi oleh logika saudagar (cara berpikir bisnis) menjadi salah satu indikator makin jauhnya nilai ideal keadaban publik di tengah bangsa Indonesia . Gejala tersebut makin mencuat dalam dunia yang dikuasai oleh kapitalisme transnasional (kapitalisme lanjutan) karena kapital atau modal menjadi titik tolak untuk membentuk kesadaran dalam memandang dunia. Fristian Yulianto memaparkan pandangan Frederic Jameson tentang dominasi kapitalisme ini dalam tulisannya yang berjudul ‘Budaya dalam cengkeraman kapitalisme transnasional: membaca realitas sosio-kultural bersama Frederic Jameson' Pada akhirnya capital transnasional akan melahirkan logika produksi 
budaya sendiri yang ditandai dengan beberapa gejala seperti (1) banalitas, (2) krisis historisitas, (3) intensitas, (4) relasi yang erat dengan teknologi dan (5) determinisme terhadap kapitalisme transnasional (hlm.36)

Pemaparan dari beberapa penulis, seperti Francis Lim, J. Supriyono, Masco SP Sinaga, Eko Sulistyo, dan Thomas Ambar menitikberatkan pada persoalan manusia. Apakah subjek itu perlu membingkai dirinya? Pendapat Francis diuraikan dengan menelusuri pemikiran Heidegger. Bagi Heidegger, membingkai adalah cara manusia mengobjekkan dunia dan pengalamannya dengan cara dan tujuan tertentu (hlm.54). Sejalan dengan pandangan Heidegger, in der Welt sein, maka manusia perlu bersinergi secara bebas dengan teknologi agar eksistensinya menjadi lebih optimal. Manusia sebagai pelaku budaya, penuh dengan kepelakuan (agency) dan subjektivitas. Agaknya itulah yang ingin disampaikan J. Supriyono, bahwa korupsi berada dalam subjektivitas (hlm.72). Lalu subjektivitas seperti apa yang berada dalam tindak korupsi? Subjek yang patuh pada norma, aturan yang berlaku ataukah subjek yang liar dengan kehendaknya demi mencapai tujuan pribadi? Supriyono ingin melihat juga bahwa ada hubungan antara kekuasaan dan bahasa dalam pandangan Roland Barthes (hlm.73). Subjek adalah sumber kekuasaan dan bahasa berada locus kekuasaan, sehingga apa yang diinginkan subjek harus terpenuhi, dan hal inilah yang akan menimbulkan korupsi kekuasaan atau penyelewengan kekuasaan.

Manusia berkesadaran ala Feurbach ingin disampaikan oleh Masco SP Sinaga. Ia mengemukakan sejauh manusia memiliki kemampuan berpikir, rasional, kemanusiaan yang sempurna dan identik dengan Tuhan serta memiliki hakikat fenomenologis (hlm. 98-99). Dengan melihat realitas yang sangat kompleks, manusia melalui kesadarannya dapat memahami dan merasakan apa yang dirasakan sesamanya serta memperluas ruang keprihatinannya terhadap apa yang diderita manusia. Realitas yang kompleks bahkan porak poranda dapat menghinggapi manusia dan membuatnya menjadi putus asa untuk memperbaiki nasibnya. Tulisan Eko Sulistyo ini menawarkan pemulihan terhadap pemahaman diri manusia (hlm. 126). dalam masyarakat yang dicirikan oleh kapitalisme. Agaknya telah terjadi ketimpangan dalam diri manusia sejak masa modern didengungkan. Kapitalisme dengan masyarakat modern telah membuat individu menjadi sangat rasional dan terkotak kehidupannya dengan dunia perdagangan, dunia keuntungan yang bersifat materialistik. Padahal manusia dengan personanya berusaha memperbaiki sisi kehidupannya sejalan dengan proses modernisasi yaitu dengan memulihkan diri dan ini akan berakibat munculnya pemulihan diri secara kolektif (masyarakat).

Tulisan yang berjudul 'Makna eksistensi manusia dalam subyektivitas dan individualitasnya' disampaikan oleh Thomas Ambar melalui cara pandang dari Kierkegaard. Individu seharusnya tetap berkomitmen dan berada pada kebenaran yang dipercayainya dalam sisi batinnyadan hendak dipeluknyadengan penuh hasrat yang mungkin sekali berbeda dengan orang lain (hlm.151). Eksistensi manusia akan menjadi lebih baik atau mengarah 
pada eksistensi sejati apabila berada pada individu bukan pada masyarakat atau massa. Melalui (subjektivitas, pen.) dan individualitas maka seseorang dapat menghayati dan merealisasikan sikap moral lebih baik daripada perilaku moral kolektif.

Di sisi lain, otentisitas individu memang dapat menjebak orang dalam subjektivisme dan perilaku moralnya. D.S. Octariano ingin mengemukakan pendapatnya melalui cara pikir Mohamad Ali Shomali, filsuf kontemporer Iran bahwa dasar moralitas yang kokoh adalah cinta diri.Cinta diri dan moralitas memang terkait satu dengan yang lain. Moralitas di dasarkan atas hasrat alamiah seseorang untuk memperbaiki diri sendiri dan keinginanya untuk mencapai cita-citanya (hlm.172). Dalam pandangannya, Shomali mengemukakan bahwa sistem moral manusia didasarkan atas cita-cita moral yang menuju tujuan akhir yaitu kebaikan tertinggi. Oleh karenanya cinta diri dapat menjadi salah satu pemicu bagaimana praktik korupsi itu muncul. Cinta diri yang tidak berada ruang lingkup etika akan berdamapak pada baik atau buruknya perilaku seseorang ketika ia harus mengambil keputusan yang terkait dengan kepentingannya.

Keprihatinan tentang kehidupan manusia masih menjadi sorotan Alfonsus Biru Kira yang menulis tentang 'Hermeneutika untuk zaman global' menurut George F.Mclean. Tulisan Alfonsus berpijak pada empat hal, (1) masa krisis di millennium ketiga, (2) kemendesakan subjektivitas dan realisasi diri sebagai tanggapan atas krisis yang terjadi (3) penjelasan mengenai perkembangan (hermeneutika, pen.) yang dapat menjadi alternative pemikiran untuk menanggapi krisis yang dihadapi manusia dan (4) aplikasi hermeneutika dan relevansinya dalam kehidupan dunia dan Indonesia saat ini (hlm.187). Sebagai manusia yang memiliki kebebasan, maka ia sekaligus juga sebagai penafsir bebas, unik dan kreatif terhadap realitas yang terbuka untuk ditafsirkan dan dimaknai. Sebagai contoh, konteks Indonesia juga ditandai dengan pembelajaran akan demokrasi yang bertumpu pada kebebasan manusia. Kebebasan inilah yang menjadi peluang untuk berdialog antar unsur budaya yang berbeda. Koridor yang berbeda dan azas Ketuhanan dalam Pancasila dapat menjadi pedoman untuk melakukan tafsir bebas tersebut dengan arif.

Perjalanan manusia yang berliku dan mengalami krisis kemanusiaan harus menempuh jalan menuju kedamaian. Tulisan Windar Santoso seakan menutup buku ini dengan peringatan pada manusia bahwa harus kembali kepada pandangan filsuf dari Cina, yaitu Lao Tzu. Manusia harus mengenal kedamaian melalui keharmonisan dan keheningan (hlm.211). Harmoni artinya mengikuti 'jalan Tao' karena semuanya berjalan dengan teratur dan konstan mengikuti hukum alam. Jadi, biarkanlah semua mengalir sedemikian rupa, segala sesuatu terjadi sesuai dengan arah dan tujuannya secara alami. Seorang pemimpin harus bersama-sama melakukan kedamaian, dan keharmonisan dengan sesama manusia, lingkungan alam di sekitarnya. Ia harus berani memperbaiki segala sesuatu yang telah rusak oleh manusia (misal lingkungan, kesejahteraan dan sebagainya) dengan kembali ke prinsip Tao 
melalui kontemplasi dan sikap wu wei (sikap yang seimbang antara yang baik dan buruk) dalam berbagai situasi dan kondisi di dunia ini.

Tulisan yang padat dari sisi substansi ini sangat menarik untuk dibaca bagi kita semua terutama yang peduli terhadap krisis kemanusiaan di abad millennium ketiga. Dalam tulisan tersebut muncul juga pandangan tentang manusia yang sangat teoretis, sehingga menyulitkan para pembaca non filsafat untuk memaknainya. Agaknya krisis kemanusiaan dipahami oleh para penulisnya sebagai korupsi kemanusiaan yang berada di tengah masyarakat. Penelanjangan korupsi kemanusiaan di tengah masyarakat menyadarkan kita bahwa kita tetap pada jalur etika dan relativisme moral, agar kita tidak ditandai nantinya oleh generasi berikutnya sebagai manusia penuh korupsi.

Irmayanti M. Budianto

Pengajar FIB UI, Departemen Kewilayahan

\section{Satu Lagi Kritik Atas Dominasi HAM Barat}

Chandra Muzaffar (dkk.) Human's Wrong: Rekor Buruk Dominasi Barat atas HAM. Diterjemahkan oleh. Anam Masrur Ba`ali, (Yogyakarta: Pilar Media, 2007), CDLX Halaman.

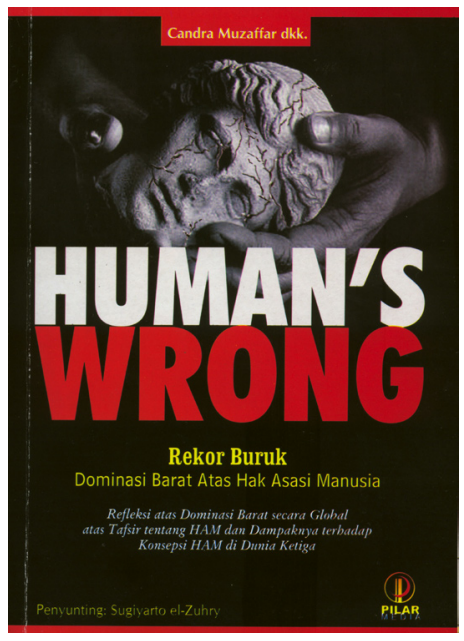

Chandra Muzaffar adalah Direktur Just Worlds Trust dan Peneliti Senior pada Science University of Malaysia. Ia juga menjadi Presiden pendiri dari organisasi nonpemerintah yang bernama Aliran Kesadaran Negara. Menulis banyak buku dan artikel ilmiah di berbagai jurnal nasional dan internasional. Dalam buku ini dia menjadi editor dan sekaligus penggagas konferensi tentang HAM yang hasilnya menjadi buku dengan judul di atas.

Buku ini merupakan kumpulan karangan (proceding) hasil Konfrensi Internasional HAM yang bertema Rethinking Human Rights yang diselenggarakan oleh Just World's Trust pada bulan Desember 1994 di Malaysia. Konfrensi itu diikuti oleh 60 pakar HAM dari berbagai negara, termasuk dari Cina, Jepang, Inggris dan Amerika Serikat. Akan tetapi oleh editornya telah ditambahkan beberapa artikel berkenaan dengan perkembangan HAM sekitar awal tahun 2000-an. Buku ini terdiri dari 4 bagian. Bagian 1 tentang HAM: Timur dan Barat yang terdiri atas 6 artikel. Bagian 2 tentang Kritik Dimensi HAM yang terdiri atas 7 artikel. Bagian 3 tentang Dampak HAM bagi Dunia Ketiga, terdiri atas 7 artikel. Bagian 4 tentang HAM: Sebagai alternatif untuk Masa Depan, terdiri atas 5 artikel. 